ELORE (ISSN 1456-3010), vol. 20 - 1/2013.

Julkaisija: Suomen Kansantietouden Tutkijain Seura ry.

[http://www.elore.fi/arkisto/1_13/lauhakangas.pdf]

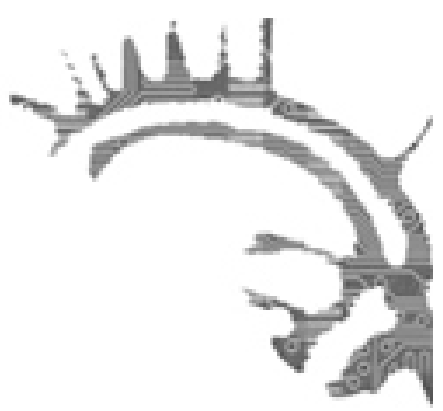

KiRJA-ARVIO

\title{
KATEGORISOINTI TUTKIMUKSEN KOHTEENA
}

JOKINEN, ARJA \& JUHILA, KIRSI \& SUONINEN, EERO 2012: Kategoriat, kulttuuri \& moraali. Tampere: Vastapaino. 296 sivua.

\section{Outi Lauhakangas}

Tamperelaiset Arja Jokinen, Kirsi Juhila ja Eero Suoninen julkaisivat jo kaksikymmentä vuotta sitten yhteisen kirjan diskurssianalyysistä ja syvensivät aiheen käsittelyä vielä 1999 ilmestyneessä oppikirjassaan. Nyt sosiaalityön professoreina ja sosiaalipsykologian yliassistenttina ja dosenttina sama kirjoittajatiimi tarttuu entistä laajempaan tehtävään. Rajaus tehdään sentään ihmistä koskevaan kategorisointiin. Kirjoittajat näyttävät kuinka kategorioiden syntymistä ja ylläpitämistä on mahdollista tutkia etnometodologian keinoin.

Jo 1960-luvulla vaikuttaneen sosiologi Harold Garfinkelin kehittämän etnometodologian tavoitteena ei ole selittää ihmisten toimintaa ja sen motiiveja eikä osoittaa, mitä normeja noudatetaan tai mitä arvoja ja sosiaalista järjestystä käyttäytyminen heijastaa, vaan keskitytään tutkimaan kysymyksiä: Miten kategorioiden keskinäinen järjestys syntyy? Missä yhteyksissä asioita nimetään? Ja millaisin seurauksin?

Uuden oppikirjan vankka pohja saadaan sosiologi Harvey Sacksilta. Hänen jäsenyyskategorisoinnin analyysi -luentonsa muistiinpanot julkaistiin postuumisti. Metodi näkyy olevan hyvin suosittu varsinkin tamperelaisissa opinnäytteissä, joita kirjan kirjoittajat ovat varmasti ohjanneet. Tutkittavaa riittää esimerkiksi siinä, millaisten kategorioiden pohjalta yhteiskunnan instituutioissa toimitaan arkisissa vuorovaikutustilanteissa.

Kategoriat ovat kielenkäytön sosiaalisia tuotteita, toisin sanoen niitä tarkastellaan sosiaalisen konstruktionismin hengessä. Kirjoittajat puhuvat metodiperheestä. Niin- 
pä myös keskustelunanalyysi on tätä perhettä. Olennaista on heidän mukaansa, että kategoria-analyysiä voi soveltaa kaikkien tämäntyyppisten metodien puitteissa.

\section{KULTTUURINEN TIETO JA MORAALINEN JÄRJESTYS}

Pitkin kirjaa muistutetaan, että kategoriat ovat kulttuurista tietoa ja tekemistä. Kun kirjan nimessä viitataan kulttuuriin ja takakansitekstissä katsotaan teoksen soveltuvan myös kulttuurintutkimuksen oppikirjaksi, olisi kulttuurintutkijan näkemys tai viittaaminen alan kirjallisuuteen laajentanut kategoria-analyysin käsittelyä. Toisaalta Kategoriat, kulttuuri \& moraali on hyvin hallittu kokonaisuus ja syventyy runsaine aineistoesimerkkeineen pääaiheeseensa, kategoria-analyysiin.

Käsittelyn ulottaminen moraalitutkimukseen olisi varmasti vaatinut huomattavasti lisäsivuja. Tyytykäämme siis etsimään lähteistä viitteitä moraaliaiheeseen ja sen pohtimiseen, mitä moraalinen järjestys, moraalinen identiteetti, moraalinen selonteko ja moraalinen järkeily oikeastaan tarkoittavat. Kirjoittajat viittaavat muun muassa Lena Jayyusin huomioon, että käytännöllinenkin selonteko on aina arvovarattua, ei siis koskaan neutraalia. Moraalisen käsitettä olisi voinut hieman purkaa esimerkiksi käsittelemällä sitä, mihin käsitykset oikeasta ja värästä tai hyvästä ja huonosta ovat sidoksissa.

Kirjoittajien mukaan arkisissa tavoissaan selostaa ja selittää, perustella ja oikeuttaa tekemisiään ihmiset herättävät henkiin kategorioita ja rakentavat niillä osaltaan sosiaalista järjestystä. Toisaalla he kirjoittavat moraalisesta järjestyksestä, joka on "kulttuurista tietoa siitä, miten eri tilanteissa tulee toimia ja käyttäytyä’. Kiinnostaisi kuulla enemmän muuhun kuin kirjoittajien mainitsemaan oikeuksiin ja velvollisuuksiin perustuvasta moraalisesta järjestyksestä. Oletan, että tässä tuottamisessaan ihmiset eri kulttuureissa luovat myös eri tavoin arvovarattua järjestystä. Olisiko kulttuurintutkijoilla tai kulttuurien tutkijoilla tähän sanottavaa?

\section{KULTTUURI YHTEISENÄ JA UUSIUTUVANA TIETOVARANTONA}

Etnometodologian avain on itsestään selviksi tulleiden käytänteiden, puhetapojen ja järkeilyjen tutkimisessa. Tilannekohtaisiin käytäntöihin ja päätelmiin taas päästään kiinni, kun tutkitaan ihmisten tapoja kuvailla asioita. Kirjoittajien mukaan kuvailu on samalla väistämättä luokittelua ja kategorioiden nimeämistä. Tutkijan tehtävä on tunnistaa kategorioita ja niiden yhteenliittymistä esimerkiksi kategoriapareiksi.

Kirjassa tuodaan monipuolisesti esiin kategorian ylitysten, muutosten, poikkeamien ja odotusten rikkomisen yhteys selontekovelvollisuuteen. Yksilöpsykologisen kognitiivisen painotuksen sijaan huomio on sosiaalisissa teoissa. Jopa tunteita, asenteita, motiiveja ja muistoja lähestytään ihmisten keskinäisen toiminnan resursseina.

Perinteentutkijoilta toivoisi kannanottoa tämän oppikirjan tietokäsitykseen. Onko niin, että kulttuuri on palautettavissa arkisissa rutiineissa ja puhetavoissa «jatkuvasti uusiutuvaksi tietovarannoksi»? 


\section{KATEGORIA-ANALYYSIEN VOIMA}

Kirjan harmaalle pohjalle painetuissa aineistoesimerkeissä ja niiden analyyseissä tulee esiin tärkeitä huomioita. Sensaatiolehti onnistuu herättämään uteliaisuutta uutisoidessaan kulttuurista ymmärrystämme horjuttavia tapauksia. Jäsenyyskategorioiden väliset epäsuhdat ja siitä syntyvä jännite pakottaa etsimään selityksiä. Syntyy paineita järjestää uudelleen me ja he -asetelmia. Kategorioista saadaan uusia resursseja ja niiden mukaan voidaan orientoitua vastaavissa tilanteissa. Tämä tuo mieleeni oman tutkimusaiheeni, sananlaskujen käytön mekanismit. Sananlaskutkin ovat mieleen ja puheeseen herätettäviä kategorioita, joilla tilanteita tulkitaan ja omia päätelmiä yleistetään.

Folkloristisen tutkimuksen kannalta kiinnostava käsite on auktorisoitu selittäminen. Kirjoittajien mukaan omassa kulttuurissamme auktorisoitu selittäminen liittyy asiantuntijoiden kategoriaan, jopa velvollisuuksiin toimia selittäjinä. Tarinan kerronnan kannalta taas uskottavuutta lisää autenttisuus. Kirjassa erotellaan asian tai tapahtuman itse kokeneen kategoria. Henkilökohtaisuus tuottaa selonteko-oikeuden. Asiantuntijan positiosta (asemasta muihin nähden) kiistellään eli neuvotellaan, mistä kategoriasta käsin on eniten valtaa, oikeus ja velvollisuus selittää, miten asiat ovat.

\section{HAASTATTELIJAN OPPIKIRJA}

Kaikille haastattelututkimusta tai ylipäätään haastatteluja tekeville kirjan kategoriaanalyysi on terveellistä luettavaa. Sen tiedostaminen, mitä kategorioita haastattelija houkuttelee esiin kysymyksillään ja mihin kategorioihin haastateltava omissa vastauksissaan kiinnittyy, on sekä tutkimuksessa että käytännön töissä tärkeää. Kirjassa on hyviä esimerkkejä siitä, kuinka kategoriasta toiseen siirtyminen vaikuttaa selityksiin tekojen oletetuista motiiveista. Jäsenkategoriathan kuljettavat mukanaan motiiveja, «luonnollisia ominaisuuksia, kykyjä, oikeuksia ja velvollisuuksia.

Haastattelututkimusten kannalta on hyödyllistä perehtyä myös kirjan ansiokkaaseen lukuun identiteettien rakentumisesta. Identiteettikategoria on niin keskeinen, että siihen palataan kirjassa yhä uudestaan. Sosiaalipsykologi Suoninen käyttää Don Zimmermanin yleisyystason mukaista identiteetin jaottelua, mukana kulkeva, tilanteinen ja vuorovaikutusidentiteetti. Tilanteen vaikutusta ei joka tapauksessa koskaan ole aihetta sivuuttaa. Persoonaankin liittyvät tuntomerkit ovat kategoriassa mukana sen mukaan, mikä painoarvo niille kussakin tilanteessa annetaan. Tilanteista identiteettiä voi verrata roolin käsitteeseen. Vuorovaikutusidentiteetistä taas on kysymys kun haastateltu ymmärretään vaikkapa jutunkertojaksi tai kun haastattelija käsitetään kriitikoksi tai vastapuolen edustajaksi. Analyysivaiheessa on mahdollista tutkia, kuinka haastateltava (tai haastattelija!) puhuu itsensä sopivaan kategoriaan.

Kategorioista puhuttaessa ei voida välttää kysymystä leimaamisesta, leimautumisesta ja leimatusta identiteetistä. Valtaa käsitellään kirjassa useassa yhteydessä. Juhila kiinnittää huomion vertailuun poikkeavuuden rakentajana. Aina ei ole itsestään selvää, onko luokittelijalla ja luokitellulla sama käsitys ryhmään tai kategoriaan kuulumisesta. Erityi- 
sesti sosiaalisten ongelmien kategorisoiminen on aina kriittistä. Ryhmään kuuluminen merkitsee tiettyyn kategoriaan kuulumista ja vaarana on stereotypisoiva kategorisointi.

Jokisen yksin kirjoittamassa viimeisessä luvussa muistutetaan, että tutkimusmetodien valinnassa analyysi on kohdistettava institutionaalisten kategorioiden voimaan, siihen valtaan, mitä niiden ohjaamassa vuorovaikutuksessa käytetään. Oheislukemistoksi kannattaa etsiä käsiinsä Ulla Tiililän väitöskirja (2007) teksteistä viraston työssä.

\section{KiRJALlisuUs}

TIILILÄ, ULLA 2007: Tekstit viraston työssä. Tutkimus etuuspäätösten kielestä ja konteksteista. Helsinki: SKS.

Valtiotieteiden tohtori Outi Lauhakangas on helsinkiläinen sosiaalipsykologi ja perinteentutkija. 